\title{
Complete Inversion of Epiglottis During Swallowing
}

National Cancer Institute

\section{Source}

National Cancer Institute. Complete Inversion of Epiglottis During Swallowing. NCI

Thesaurus. Code C127241.

A finding of complete inversion of epiglottis during swallowing. 